\title{
EXPERIMENTAL AND ANALYTICAL STUDIES ON SEISMIC RESPONSE BEHAVIOR OF HTGR CORE
}

\author{
PART II
}

- Analytical Study on Dynamic Response Characteristics-

\author{
By Kiyoshi MUTO*, Takashi KURODA** and \\ Hiromoto TAKASE****, Members of A.I.J
}

\section{INTRODUCTION}

This paper deals with the Part II of experimental and analytical studies on the seismic response behavior of an HTGR (High Temperature Gas-cooled Reactor core. Part I described an experimental portion of the studies. Reported herein is an analytical review of the dynamic response characteristics of the core. Firstly a summary of the analytical methods for a series of the computer codes "COLLAN" developed in parallel with the model tests is presented. The validity of analytical methods is verified by correlation with test results, and then the response characteristics of the core are analyzed by COLLAN with respect to major parameters relating to collision dynamics.

As was already mentioned in Part I, similar studies have been or are being conducted by others. The basic approach taken for these programs in common including authors' is to ultimately develop computer codes capable of predicting the collision behavior of the core. These codes are grouped into three categories; one-, two- and three- dimensional codes.

One-dimensional $(1-D)$ codes model a horizontal strip across the core and have been developed by Rickard ${ }^{12}$, Laskal et $\mathrm{al}^{2)}$, Ishizuka et $\mathrm{al}^{32}$, Ikushima et $\mathrm{al}^{4)}$ and others. Studies have been conducted by Tow $^{5}$ and others on two-dimensional (2-D) computer codes which can treat motion in a horizontal slice of the core. The code is in principle similar to a $1-D$ code except for the provision for planar motion, and is used to aid a $1-D$ code in providing two-dimensional effect. 2-D vertical codes were also developed by Lee et $\mathrm{al}^{6)}$, Thompson ${ }^{7)}$, Laskal et $\mathrm{al}^{2)}$, Ide et $\mathrm{al}^{8)}$ and others, which are capable of handling motion in a column or in a series of columns in a vertical slice of the core.

These $1-D$ and $2-D$ codes are generally shown to provide good correlation with test data, although further correlation studies are still being conducted on some computer codes. Especially it can be said that, since excellent correlation was achieved, a 1-D code has been advanced to the point that it can be used not only for parametric studies but also for design purposes. Attempts have been made to develop a three-dimensional $(3-D)$ computer code by Muto et $\mathrm{al}^{93}$ and Subudhi et $\mathrm{al}^{10)}$, and further development is expected in the future.

Upon development of the above-mentioned computer codes, efforts have been made to establish mathematical models best simulating collision dynamics. These include impulse-momentum, visco-elastic and non-linear spring-damper systems. In addition a hybrid impulse and spring system has been developed by GAC (General Atomic Company) for their computer codes ${ }^{11)}$.

Authors have employed an impulse-momentum approach for their $1-D$ and $2-D \operatorname{codes}^{12), 13), 14)}$ which, unlike most of the other computer codes, are characterized by their capability of treating a full array of elements with practical computer running time. In the authors' study the emphasis has been laid on

* Member of Japan Academy, Professor Emeritus, University of Tokyo President, Muto Institute of Structural Mechanics, Inc.

** Nuclear Power Department, Electric Power Development Co., Ltd.

*** Muto Institute of Structural Mechanics, Inc. 
correlation between test and analysis regarding the essential parameters affecting collision dynamics. It was also considered important to estimate the overall dynamic response characteristics rather than the detailed characteristics of individual elements.

\section{SIMULATION ANALYSTS}

2.1 Analytical Method

Although it is theoretically possible to develop a three-dimensiona? (3-D) computer code, it was deemed impractical at this stage to use it as an analytical tool because of enormous amount of computing time required as it must deal with approximately 8000 blocks. Instead, three computer codes with efficient mathematical formulations have been developed to handle smaller portions of the core represented in one- and two-dimentions; i.e. COLLAN 1 for a one-dimensional (1-D) horizontal array, COLLAN 2- $I$ and COLLAN 2- $V$ for two-dimensional (2-D) horizontal and vertical sections respectively. Three-dimensional effects can be incorporated by employing adequate factors to be derived from a comparison between the $3-D$ scale model test results and the $1-D$ or $2-D$ analytical predictions.

A detailed description of analytical techniques is not presented because of limitation in space, but an outline of the three computer codes is described below with emphasis on the main features.

COLLAN $1^{12}$ is a one-dimensional code which models a horizontal row of hexagonal blocks and permanent side reflectors across the core, in which each block is idealized as a circular puck (Fig. 1). The individual blocks are suspended as pendulums or supported by springs, and are separated with gaps. Column stiffness effects are represented as springs. A permanent side reflector at either end is provided with a spring-damper system simulating a side support spring (spring pack). An impulse-momentum approach is employed in COLLAN 1 to deseribe the element-to-element collisions, where

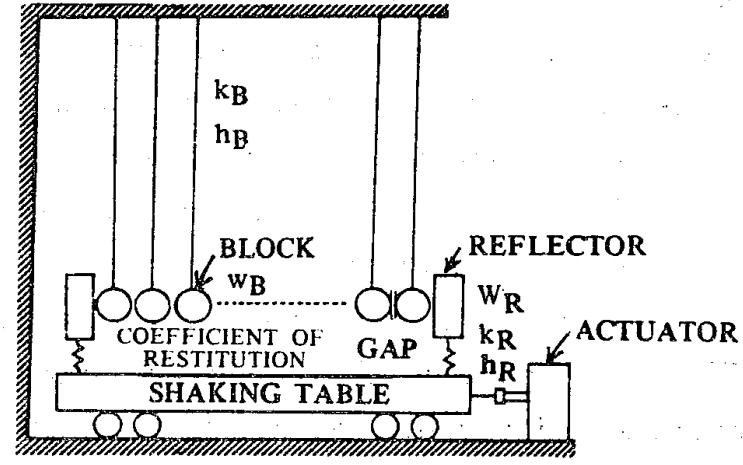

Fig. 1 COLLAN 1 model (1-D horizontal) each element is assumed to be a rigid body. The element velocities before and after a collision can be derived from the collision theory based on a constant coefficient of restitution and the law of conservation of momentum. Because of excellent correlation with test data and less computing time, COLLAN 1 was found to be a useful tool for design as well as parametric studies.

COLLAN $2-H^{13}$ analyzes a complete horizontal array of hexagonal blocks and permanent side CORNIE - TO CORNIER DIRECTION

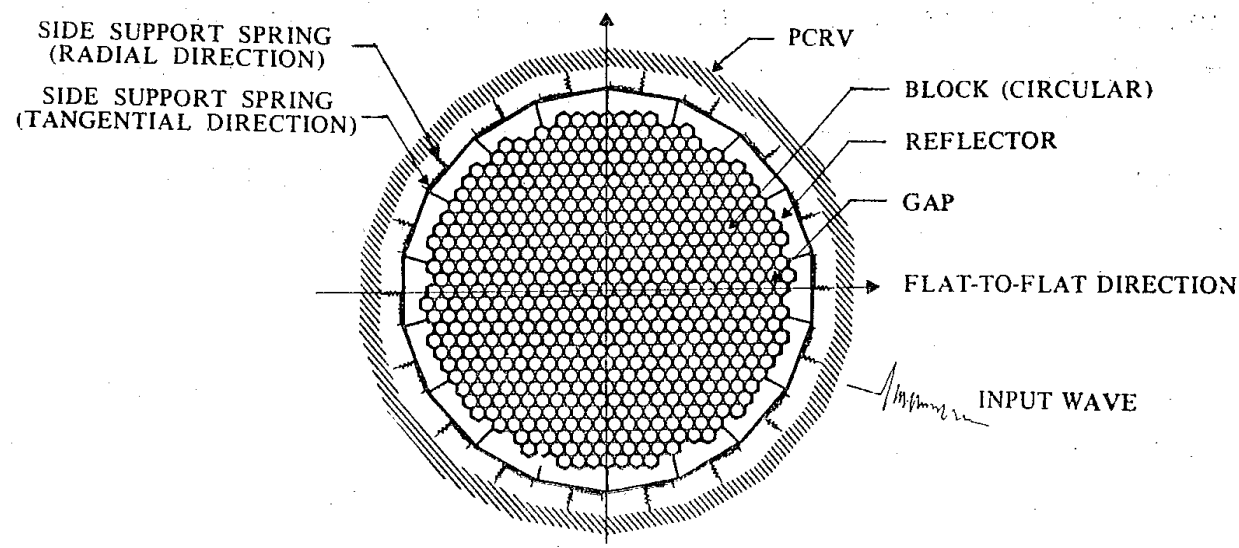

(a) PLAN OF MODEL

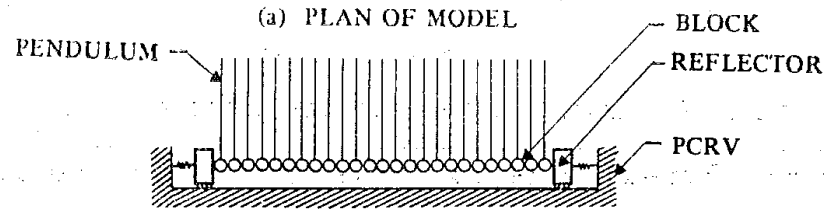

(b) SECTION OF MODEL

Fig. 2 COLLAN 2-H model (2-D horizontal) 
reflectors including side support springs (Fig. 2). The code is essentially similar to COLLAN 1 except for the two-dimensional features. In the code, computation is made as iteration of collision between elements. Similar to COLLAN 1 each element is assumed to be a rigid circular body, but both rotation and friction between blocks are neglected. Collision theory assuming a constant coefficient of restitution is applied to the variation of velocity only in the normal direction, while the variation of velocity in the tangential direction is disregarded. For the vibration system of reflector and side support spring, springs and damping factors are considered in both normal and tangential directions. Sinusoidal and random input motions can be imposed at the model boundary in any directions desired, thus yielding the response such as block motion and reflector reaction. Furthermore simultaneous input of two motions in two horizontal directions is possible.

COLLAN $2-V^{14)}$ is a two-dimensional code to analyze a vertical slice of the core consisting of stacked columns including permanent side reflector stacks and side support springs at either end (Fig. 3). The code empolys a new analytical technique ${ }^{15)}$ developed for this study which is characterized by expressing both coordinate and its kinetic system of vertical columns by complex numbers of plane vector. In the code, both horizontal and vertical collisions are expressed mathematically by the impulse-momentum technique. Namely the principle of conservation of momentum is applied for movements of translation and rocking of blocks. The assumptions are made in the code that the upper and lower blocks are connected each other at the corners, and that the collision between upper and lower blocks ends in an instant when the rigid bodies collide with each other. The collision between horizontal blocks is analyzed by the collision theory based on a constant coefficient of restitution. For the vibration system of reflector and side support spring, springs and damping factors are considered. Compressive force corresponding to helium gas flow can be incorporated at the top of columns. In addition to excitation in the horizontal direction, simultaneous input of horizontal and vertical motions is possible.
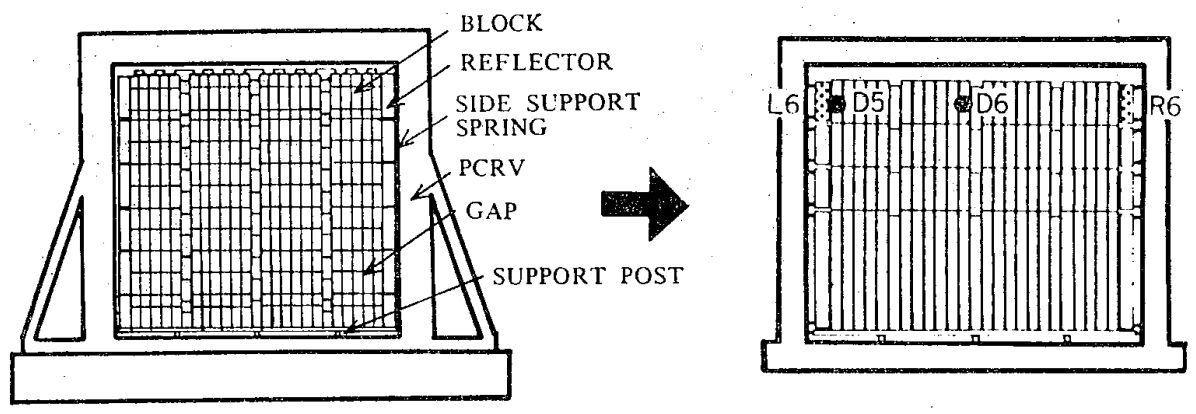

Fig. 3 COLLAN 2- $V$ model (2- $D$ vertical)

\subsection{Correlation Between Test and Analysis}

This section describes the correlation between test and analysis with regard to $1 / 5$ scale $1-D$ horizontal, 2-D horizontal and $2-D$ vertical models. Analytical models shown in Figs. 1, 2 and 3 were used in the analysis. For the analysis of a $2-D$ vertical model, however, computation was made by reducing full blocks into four layers in light of the mode of block displacement (Fig. 5) derived from the preliminary analysis for a full model.

Analyses were performed with the same boundary excitation as was used in the test, and typical examples of the comparisons between test results and analytical predictions are indicated in Fig. 4. Main input data for each analysis are given below, among which the numerical values of coefficient of restitution and damping factor for each model were determined in consideration of the collision dynamics characteristics inherent in each section of the core.

$1-D$ horizintal model $\cdots$ weight of block $: 0.8 \mathrm{~kg}$, gap between blocks $: 0.08 \mathrm{~cm}$, coefficient of restitution : 0.65 , weight of reflector $: 1.6 \mathrm{~kg}$, stiffness and damping factor of side support spring $: 2,200 \mathrm{~kg} / \mathrm{cm}$ and 0.50 , input waves : sinusoidal wave $(0.1 \mathrm{~g}, 1.5 \mathrm{~Hz})$ and $\mathrm{El}$ Centro (1940 NS) wave $(0.5 \mathrm{~g})$, computation time interval : 0.001 sec.

2-D horizontal model $\cdots$ the same as $1-D$ horizontal model except for weight of reflector $: 15 \mathrm{~kg}$, 


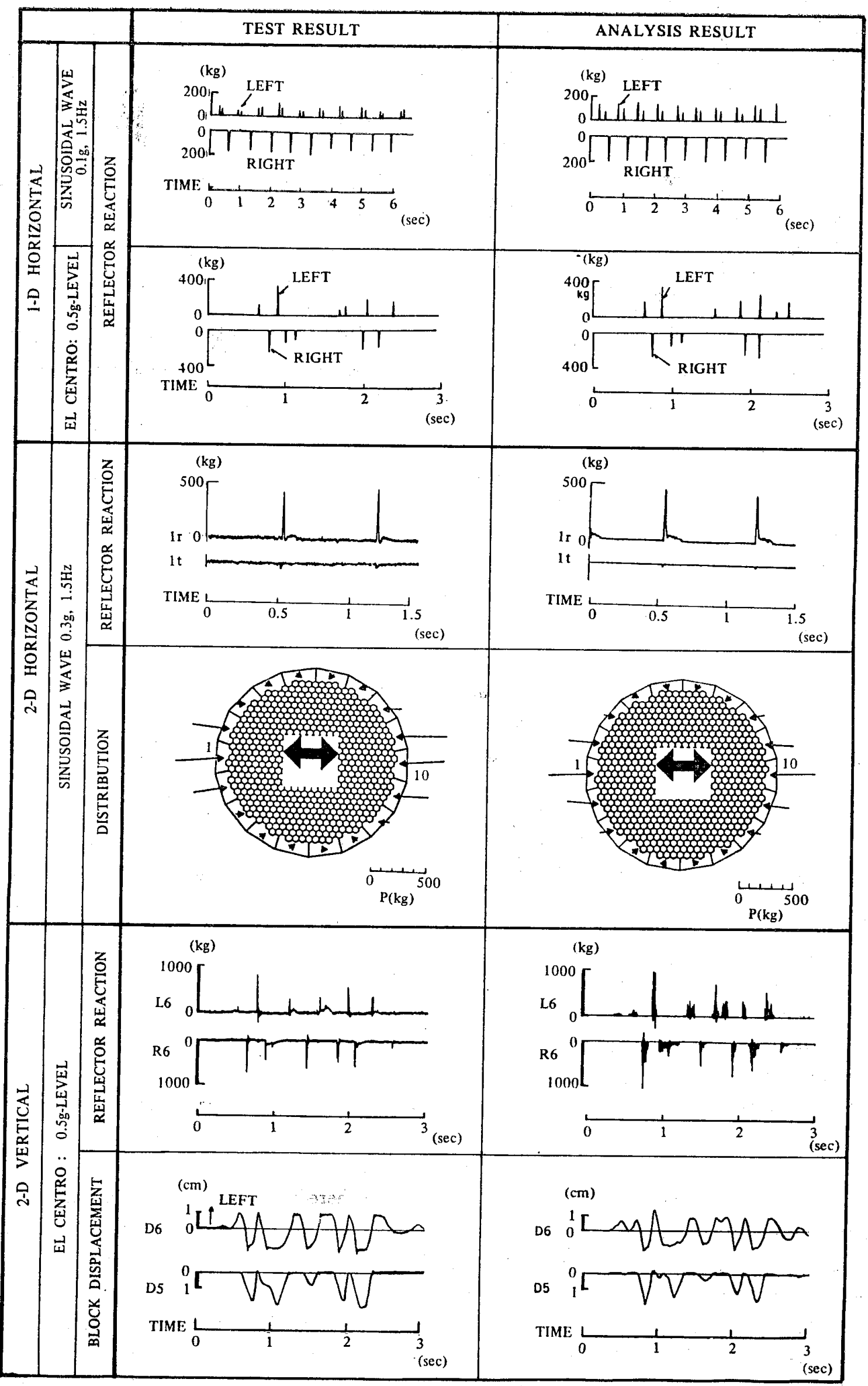

Fig. 4 Comparison between test and analysis 


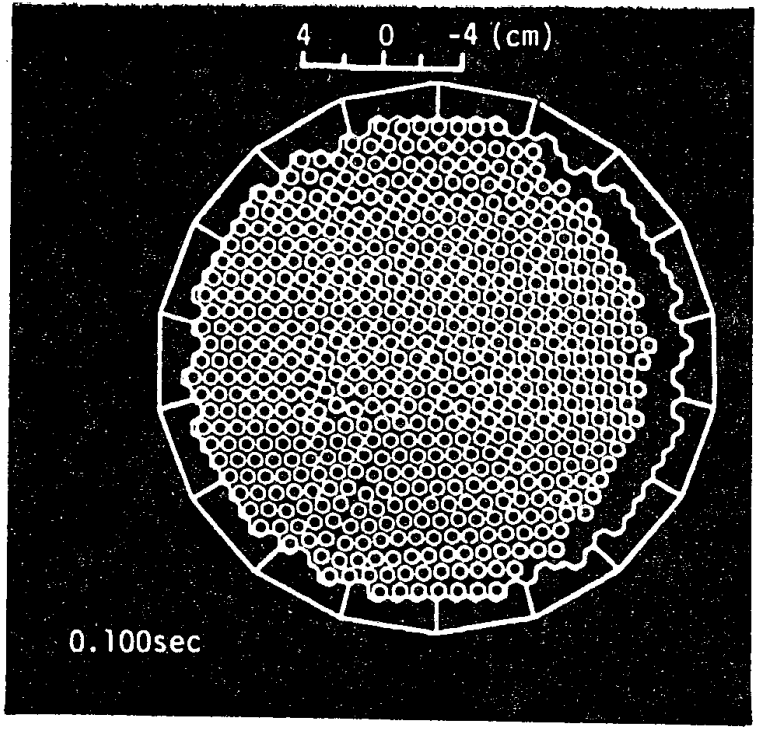

(a) 2-D HORIZONTAL MODEL

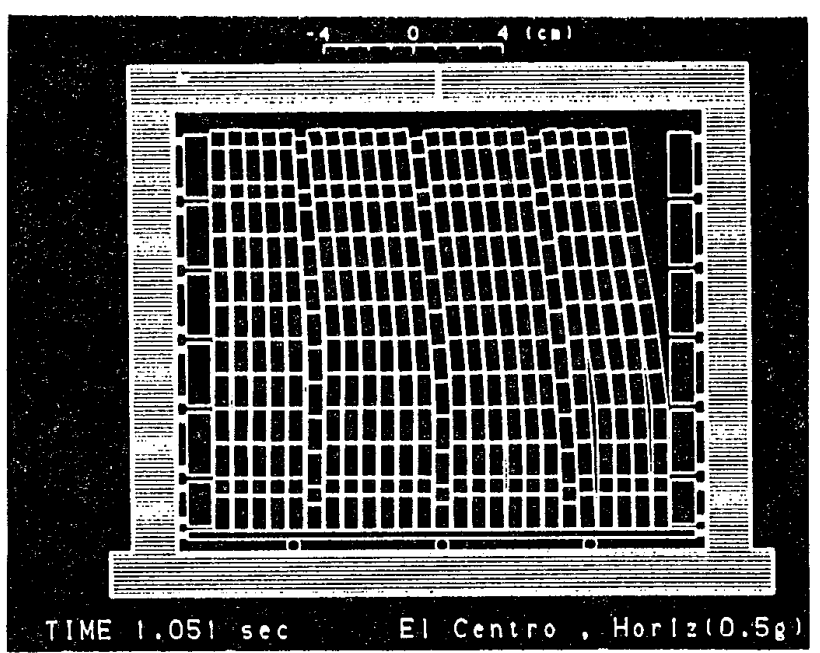

(b) 2-D VERTICAL MODEL

Fig. 5 Block motion by analysis

stiffness of side support spring: 10,000 kg/cm (both radial and tangential directions, equivalent to five rows of blocks), input wave : sinusoidal wave $(0.3 \mathrm{~g}, 1.5 \mathrm{~Hz})$.

$2-D$ vertical model $\cdots$ the same as $1-D$ horizontal model except for coefficient of restitution $: 0.90$, weight of reflector: $3.6 \mathrm{~kg}$ (equivalent to two layers of blocks), stiffness and damping factor of side support spring: $4,000 \mathrm{~kg} / \mathrm{cm}$ (equivalent to two layers of blocks) and 0.40 , input wave : El Centro wave $(0.5 \mathrm{~g})$.

As can be seen from Fig. 4, there was good agreement between the forced vibration test and analysis in every model. It will be, therefore, concluded that the computer codes COLLAN (COLLAN 1, COLLAN 2- $H$ and COLLAN 2-V) can satisfactorily simulate the test results and can be used to predict the collision behavior of an HTGR core.

Block motion is depicted in Fig. 5 by the COM (Computer Output Microfilming), in which block displacement is enlarged by a factor of 12.5 . It is observed that blocks move in lumping in a $2-D$ horizontal model, and that displacements of columns in a $2-D$ vertical model are caused by rocking of individual block and the upper part of columns vibrate in lumping with the first mode.

\subsection{Model Scaling Laws and Verification of Dynamic Similitude in Analysis}

As was already presented in 2.2, good correlation was achieved between the 1/5 scale model test results and analytical predictions. Then the validity of dynamic similitude in analysis was confirmed using COLLAN 1 by extrapolating the collision dynamics analysis from $1 / 5$ to full scale.

Assuming that $1 / 5$ and full scale blocks are rigid bodies having the same density the analyses were conducted on the two scale models using the input data which meet the theoretical scaling factors led from dimensional analysis of the essential variables governing the collision behavior of the core. The scaling factors derived from the analyses for maximun block displacement, block impulse, reflector reaction are in good agreement with the theoretical ones. Therefore the scale relationship of $1 / 5$ scale to full scale as to the major physical quantities of interest was analytically assured to be valid andshown below, where the scale factor $\lambda$ is a constant.

Length, displacement

Velocity, time

Frequency

Acceleration, coefficient of restitution : 1

Block impulse

Reflector reaction
$: \lambda$

$: \sqrt{\lambda}$

$: 1 / \sqrt{\lambda}$ 
Scaling laws mentioned above are applicable to the response characteristics of a horizontal slice of the core. Next, the applicability of these scaling laws to a vertical slice of the core is investigated ${ }^{16)}$. Fig. 6 shows the time histories of impulse $\left(N^{*}, Q^{*}\right)$, force $(N, Q)$, displacement $(V, U)$, velocity $(\dot{V}, \dot{U})$, acceleration $(\ddot{V}, \ddot{U})$ and rotational displacement $(\theta)$, velocity $(\dot{\theta})$ and acceleration $(\ddot{\theta})$ of a single block when subjected to rocking motion. The analysis was performed on both $1 / 5$ and full scale blocks. From this result the relationship indicated above is found to hold for the law od similitude with respect to all the variables, except for rotation of a block.

\section{DYNAMIC RESPONSE CHARACTERISTICS PERTAINING TO MAJOR PARAMETERS}

Analysis was made by COLLAN 1 for a $1 / 5$ scale $1-D$ mathematical model of the straight array across

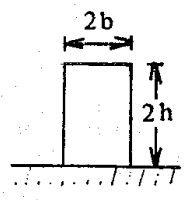

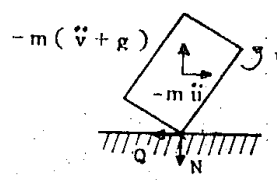

FORCE
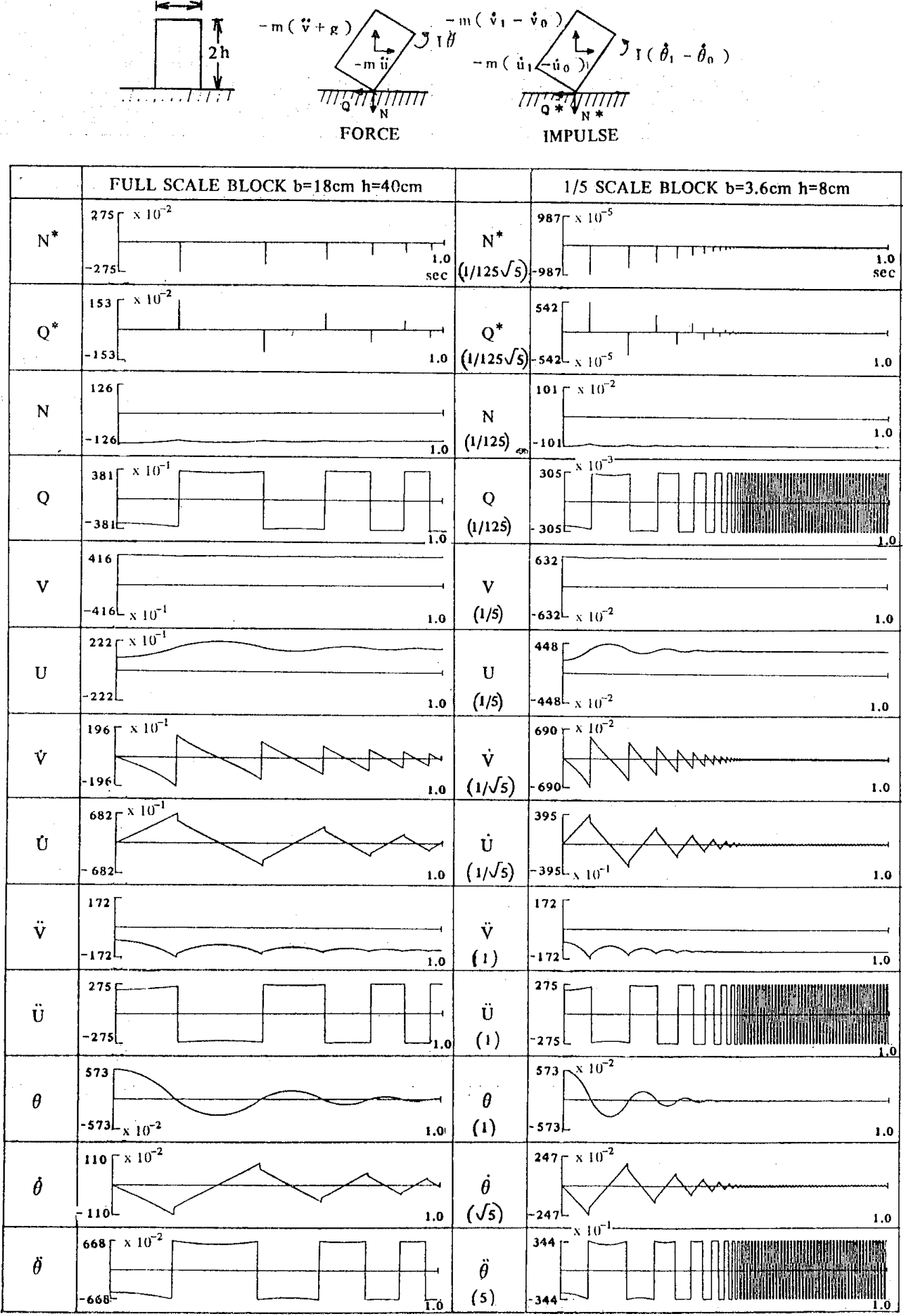

Note: ( ) denotes the scaling ratio of $1 / 5$ to full scale for each physical quantity.

Fig. 6 Time history of one block rocking motion 
the core to see the influence of major parameters relating to collision on the response of the core. The parameters examined are stiffness and damping factor of side support spring, gap between blocks, coefficient of restitution and column spring.

For the analysis, the 1-D model shown in Fig. 1 and the input data indicated in 2.2 were utilized. Major analytical results are given below.

\section{(1) Side support spring}

Stiffness $\cdots$ indicated in Fig. 7 are the maximum reflector reactions and reflector impulses for three different springs, 80,700 and $2,200 \mathrm{~kg} / \mathrm{cm}$, for the same sinusoidal input wave as was used in the correlation for a $1-D$ model (amplitude $D=1.2 \mathrm{~cm}$, frequency $f=1.5 \mathrm{~Hz}$ ), where the reflector impulse is defined as an area under the reflector reaction -contact time curve. It was found from these results that the reflector reaction increases in proportion to the square root of its stiffness, whereas on the contrary, the duration of contact time decreases, and as a result the reflector impulse tends to vary little. It was also found from the slow motion representation of reflector impulses that the duration of each reaction $(0.065,0.025$ and $0.018 \mathrm{sec}$ ) corresponds to about 60 to 90 percent of the natural frequency for a single-mass system consisting of 25 blocks and one reflector (0.104, 0.035 and 0.020 sec.).

Damping ...reflector reactions were analyzed for a model with the stiffness of side support spring of $2,200 \mathrm{~kg} / \mathrm{cm}$ for three different damping factors, $h_{R}=0.05,0.10$ and 0.50 for the reflector's natural frequency $f_{R}=185 \mathrm{~Hz}$. The analysis was conducted for the sinusoidal input wave $(D=$ $1.2 \mathrm{~cm}, f=1.5 \mathrm{~Hz}$.) to see the influence of damping on the response. Fig. 8 shows the maximum reflector reactions. From this figure it can be seen that the reflector reaction tends to increase a little with an increase in damping factor in contradiction to the seismic response of an ordinary multi-mass system. According to the reflector impulse where the time scale is enlarged, free vibration is observed to continue in cases of $h_{R}=0.05$ and 0.1 for a certain period of time after the occurence of triangular shaped impulse, while in case of $h_{R}=0.50$, almost no free vibration is seen. It is obvious that the test result having nearly no free vibration after the impulse best resembles the analytical result for $h_{R}=0.50$. This implies that the damping factor appropriate for the analysis of seismic response behavior of a reflector under collision with multiblocks would be about 0.50 .

(2) Gap between blocks

Fig. 9 presents the maximum reflector reaction and impulse as a function of gap. The analyses were performed for three different gaps, $0.02,0.04$ and $0.08 \mathrm{~cm}$ (correspond to the total gap $A$ of $0.5,1.0$ and $2.0 \mathrm{~cm}$ ) for the

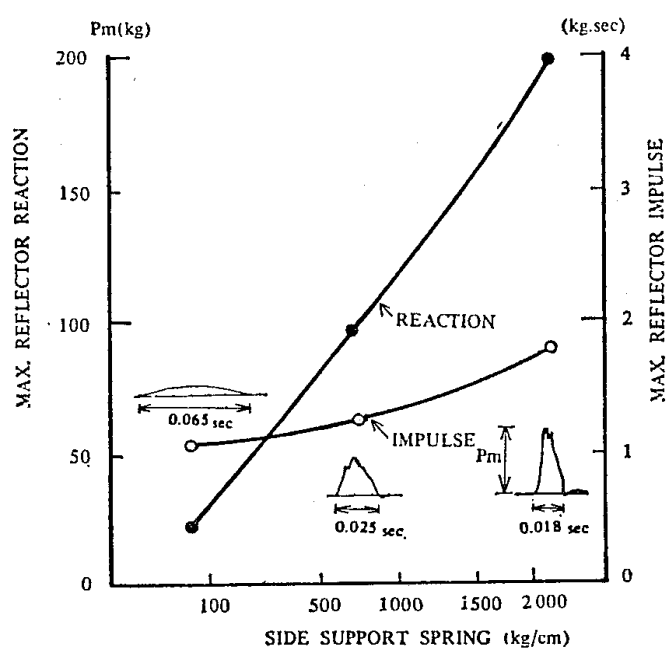

Fig. 7 Reflector reaction and impulse versus stiffness of side support spring

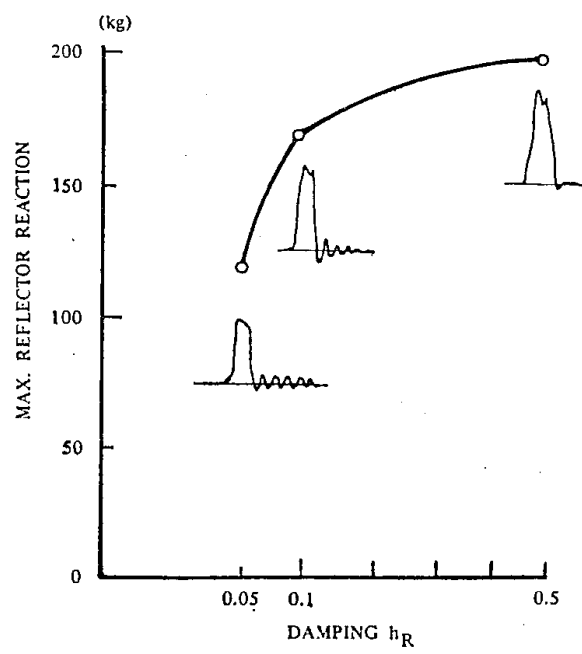

Fig. 8 Reflector reaction versus damping of side support spring

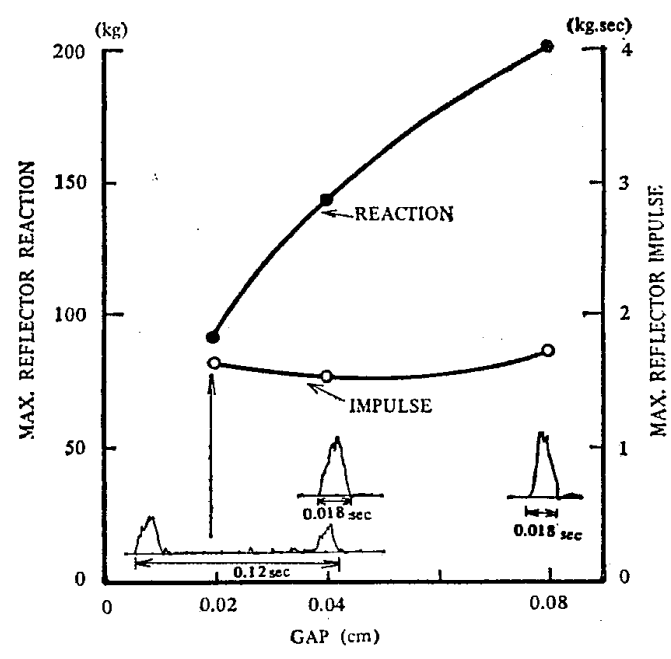

Fig. 9 Reflector reaction and impulse versus block gap 
sinusoidal input wave $(D=1.2 \mathrm{~cm}, f=1.5 \mathrm{~Hz}$.) As the gap increases, the maximum reflector reaction increases due to lumping of blocks, but the impulse is found to remain almost constant regardless of change in the impulse pattern.

(3) Coefficient of restitution

As was previously mentioned, the coefficient of restitution obtained from the test was approximately 0.65. However, since this value is considered to vary with graphite properties, block collision pattern, etc., the analysis was made on six cases with respect to coefficient of restitution, $0,0.3,0.65,0.8,0.9$ and 1.0. Input motion used was the sinusoidal wave $(D=1.2 \mathrm{~cm}, f=1.5 \mathrm{~Hz})$. Other input data used are reflector spring $: 2,200 \mathrm{~kg} / \mathrm{cm}$ and reflector damping $: 0.50$.

Fig. 10 shows the relationship between the coefficient of restitution and maximum reflector reaction. It is observed from this result that no significant differences are seen in the response pattern including the maximum reflector reaction in cases of $0,0.3$ and 0.65 . This implies that at the time of collision between block and reflector, almost all the blocks are lumped to become one body. At 0.8 and 0.9 the reaction tends to decrease markedly, and in case of 1.0 the response is considerably different (about $20 \%$ of the average for $0,0.3$ and 0.65). It is estimated that this is because less blocks are lumped due to very frequent collision between blocks.

(4) Stiffness of column spring

To date the parametric analysis has been conducted on the assumption that each block is suspended by fine wires, and hence no effect of column spring was taken into account in the analysis. However, in reality a column possesses spring effect as it is of a masonry structure consisting of graphite blocks. Accordingly the reflector reaction was computed for a column whose stiffness corresponds to $3.5 \mathrm{~Hz}$ in its natural frequency. In comparison with the analytical result for a column without spring, the reaction is indicated in Fig. 11 as a dotted line as a function of the frequency of input motion. It can be seen that the reflector reaction decreases markedly to near zero at 3 to $3.5 \mathrm{~Hz}$ in both cases. In terms of the ratio of $D / A$ ( $D:$ amplitude of input wave, $A:$ total gap), this phenomenon occurs when $D / A$ becomes about 0.3 . The same behavior was observed in $1 / 5$ scale model test. Therefore it can be said that $D / A=0.3$ is a key in judging the lumping characteristics of blocks. In conclusion as far as the

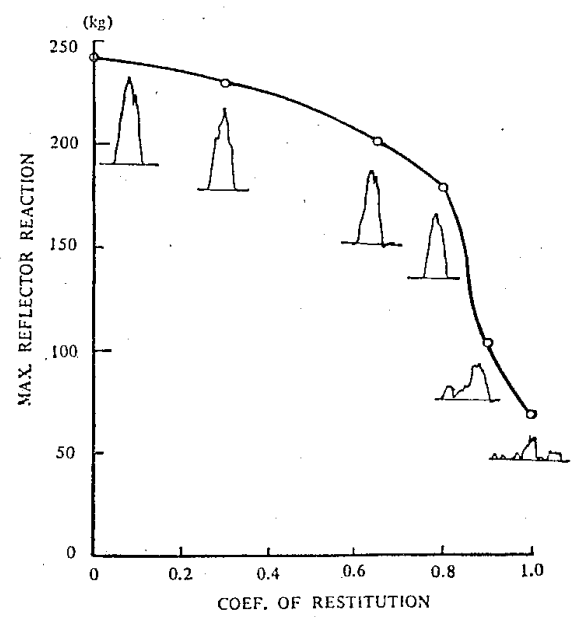

Fig. 10 Reflector reaction versus blockto-block coefficient of restitution

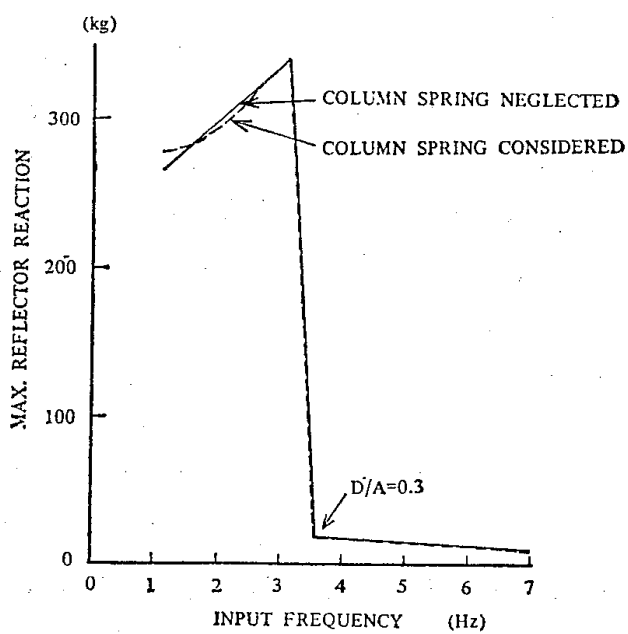

Fig. 11 Reflector reaction versus input frequency (as a function of column spring) I- $D$ analysis by COLLAN 1 is concerned, the stiffness of column spring has little effect on the response.

\section{CONCLUSION}

Through the comparison between the test and analytical results, a series of computer codes COLLAN 1, COLLAN 2- $H$ and COLLAN 2- $V$ developed based on an impulse-momentum approach were proved to be capable of simulating the collision behavior of an HTGR core when subjected to seismic excitation. Therefore it is anticipated that, with the use of the above computer codes, the seismic response of an actual core could be approximated with an acceptable degree of confidence.

Various dynamic characteristics of the core were clarified by the parametric analysis using COLLAN 1. In addition a parametric analysis was found to make an effective tool to the assessment of seismic qualification of an HTGR core. Major findings obtained from the parametric analysis are (1) reflector 
reaction increases in proportion to the square root of its stiffness, whereas reflector impulse remains almost unchanged, (2) reflector reaction tends to increase a little with an increase in damping value, (3) maximum reflector reaction increases as the gap increases, (4) no significant differences are seen in the response due to the change in coefficient of restitution in the range of 0 to 0.65 , and (5) the stiffness of column spring has little effect on the response.

\section{ACKNOWLEDGEMENT}

The authors wish to express their sincere gratitude for the guidance and encouragement received from Prof. Y. Ohsaki. The authors also wish to express their thanks to the members of Muto Institute of Structural Mechanics and Electric Power Development Company for their assistance. The authors are also indebted to General Atomic Company for their valuable information and discussions.

\section{REFERENCES}

1) N.D. Rickard, "CRUNCH 1 D, Computer Program for Seismic Analysis of the HTGR Core", GA-A 14120, March 1977.

2) L. Laskal et al, "OSCIL and OSVERT : Computer Codes to Evaluate the Nonlinear Seismic Response of an HTGR Core", K 7/2, 4th SMiRT, San Francisco, August 1977.

3) H. Ishizuka et al, "Seismic Experiment of High Temperature Gas-cooled Reactor Core Structure (1), (2)", Fuji Electric Journal, 48, (No. 8 \& 10) 1975, (in Japanese).

4) T. Ikushima and M. Kawakami, "Seismic Response Analysis for Block-type Fuel HTGR Core", K 8/7, 3rd SMiRT, London, Sept. 1975.

5) D. Tow, "CRUNCH $2 D$, a Two-dimensional Computer Program for Seismic Analysis of the HTGR Core", GA-A 14764, April 1978.

6) T.H. Lee and D.A. Wesley, "Non-linear Seismic Response of a Series of Interacting Fuel Columns Consisting of Stacked Elements", K 8/5, 3rd SMiRT, London, Sept. 1975.

7) R.W. Thompson, "MCOCO. A Computer Program for Seismic Analysis of the HTGR Core", GA-A 14728, Sept. 1978.

8) A. Ide and H. Hayakawa, "A Study on Vibration Response Analysis of HTGR Core Vertical Section and the Use of Simplified Models", 2nd U.S.-Japan Seminar on HTGR Technology, Nov. 1978.

9) K. Muto et al, "A Method of Three-dimensional Non-linear Dynamic Analysis for Stacked Blocks", 2nd U.S.Japan Seminar on HTGR Technology, Nov. 1978.

10) M. Subudhi et al, "A Three-dimensional Computer Code for the Non-linear Dynamic Response of an HTGR Core", K 12/6, 5th SMiRT, Berlin, Aug. 1979.

11) H.D. Shatoff et al, "Non-linear Dynamic Analysis of Prismatic Elements for High-Temperature Gas-cooled Reactor Cores". Preprints of Panel Session JK, 5th SMiRT, Berlin, Aug. 1979.

12) K. Muto, T. Kuroda et al, "One-dimensional Vibration Test and Simulation Analysis for HTGR Core", K 8/8, 3rd SMiRT, London, Sept. 1975.

13) K. Muto, T. Kuroda et al, "Two-dimensional Vibration Test and Simulation Analysis for a Horizontal Slice Model of HTGR Core", K 12/2, 5th SMiRT, Berlin, Aug. 1979.

14) K. Muto, T. Kuroda et al, "Two-dimensional Vibration Test and Simulation Analysis for a Vertical Slice Model of HTGR Core", K 7/8, 4th SMiRT, San Francisco, Aug. 1977.

15) K. Muto and H. Takase, "Numerical Method of Impulsive Rocking Vibration of Columns Consisting of Stacked; Elements", Transactions of Architectural Institute of Japan (AIJ), (in Japanese), (submitted for publication).

16) K. Muto et al, "Analytical Method for Collision Vibration of a Single Block by Complex Numbers of Plane Vector", Transactions of Kanto Division of AIJ, 1977 (in Japanese). 


\section{高温ガス炉 (HTGR) 炉心の地震応答性状に関する \\ 実験・解析研究 (梗概)}

その 2 動的応答特性に関する解析研究

$\begin{array}{lllll}\text { 名誉会員 } & \text { 武 } & \text { 藤 } & & \text { 清* } \\ \text { 正会員 } & \text { 黑 } & \text { 田 } & & \text { 孝** } \\ \text { 正会員 } & \text { 高 } & \text { 瀬 } & \text { 啓 } & \text { 元*** }\end{array}$

\section{1.まえがき}

本論文は，高温ガス炉 (HTGR) 炉心の地震応答性状 に関する，実験ならびに解析による研究成果の第 2 報で ある。

第 1 報では，一連の模型実験による研究成果安報告し た。第 2 報では, 実験と並行して開発した一連の解析コ 一ト COLLAN と，これによる炉心の動的応答特性の 解析検討結果を述べる。

著者らの研究では, 他の同種の研究と同様, 最終的に は HTGR 炉心の衝突現象を予测し得る解析コードを開 発することを基本的な考え方としている。

一般に, 解析コードは 1 次元，2次元および 3 次元に 分類され，米国のゼネラルアトミック社 (GAC) をはじ め，各国で開発が進められている現状にある.このう ち, 1 次元と 2 次元の解析コードは, 総じて実験結果と の対応が良好なものもあり，開発がかなり進んでいると いえる。3次元については今後の進展が期待される。

著者らが開発した 1 次元および 2 次元の衝突解析コー ト COLLAN は, 衝突理論と運動量保存則に基づく解 析理論によっている。COLLAN は，実用的な計算時間 で全要素モデルの解析が可能であることが特徴である。 著者らの研究では，衝突特性に影響する重要パラメータ について，実験との相関が成り立つこと定眼としてお り，また，個々の要素の詳細な特性よりも炉心全体の動 的応答特性の把握を重視している。

\section{2. シミュレーション解析}

2.1 解析手法

著者らは，3次元振動解析コードの開発は理論的には 可能でめっても，莫大な演算時間を要するため, 現時点 では実用上は不可能と判断し，I次元および 2 次元衝突 解析コード COLLAN (水平面 1 次元 COLLAN 1, 水

* 日本学士院会員, 東京大学名誉教授 -工博, 武藤構造力学 研究所所長

***電源開発株式会社 原子力部

*** 武藤構造力学研究所

（昭和 55 年 1 月 29 日本稿受理・討論期限昭和 55 年 9 月末日）
平面 2 次元 COLLAN 2-H, 垂直面 2 次元 COLLAN $2-V)$ を組合わせることにより，実物炉心の応答を推定 することとした。

COLLAN は，黒鉛ブロックを剛体とし， 反発係数を 一定と仮定した衝突理論と，運動量保存則に基つく解析 理論によって開発された。水平面 2 次元の場合，黒鉛ブ ロックを円形岡!体として扱い，回転および相互の摩擦は 無視し,ブロックの衝突は 2 質点の衝突の繰返しとして 計算した。垂直面 2 次元で忙，カラムの座標系执よび力 学系を平面べクトルとして複素数によって表示し, 解析 式を簡素化した手法によっている。

2.2 実験と解析の相関

このようにして開発されたコードを用い，Fig. 1，2 および 3 に示すモデルによって，1/5 紨尺模型実験をシ ミコレートする解析を行った。垂直面 2 次元の場合, 全 要素モデルの変位モード（Fig. 5）を参照し, 全体を 4 層より成るモデルに縮小して解析を実施した。代表的な 例について，解析と実験結果を比較して Fig. 4 に示し た。これから明らかなように，かなり良好な相関関係が 得られ，COLLAN によりブロックの衝笑現象が十分シ ミコレートできることを確認した.

2.3 模型の相似則と解析における相似性の実証

1/5 縮尺では，実験と解析の相関性に問題のないこと が明らかとなった．ついで，COLLAN 1 を用い，1/5 縮尺と実大との間の相似性が成立することを解析上確認 した。すなおち, 理諭上の相似率をもとにインプットデ 一タを定め，1/5 縮尺および実大の雨モデルについて解 析した結果, 得られた応答值が理論上の相似率にほぼ合 致することが明らかとなった。この相似則の垂直面への 適用性についても解析検討を加え，回転を除き，妥当で あることが分った（Fig. 6)。

\section{3. 主要パラメータに関する動的応答特性}

COLLAN 1 を使用し， 1 次元 $1 / 5$ 縮尺モデルについ て，サイドサポートスプリングの剛性および減衰，ブロ ック間のギャップ，反発係数およびカラムスプリングを 
パラメータとして, 炉心の衝突現象を数值的に 解明し た。解析結果 (Fig. 7, 8, 9, 10, 11) によると, リフ レクター反力はサイドサポートの剛性に依存し，ほぼそ の平方根に比例して増大するが，ブロックおよびリフレ クターの衝撃力積はほとんど変化がないこと，リフレク ター反力は減衰の増加にともない，わずかながら増加す ること, リフレクタ一反カの最大值はギャップの増加に ともなって増えること, 反発係数 $0 \sim 0.65$ の範囲では応 答に差がないこと， 1 次元モデルに関する限り，カラム の剛性は応答にほとんど影響しないことなどの特性が明 らかとなった。

\section{4. 結 論}

解析と実験との対応により衝突解析コード COLLAN
を使用すれば，地震時における HTGR 炉心の挙動を予 測することが可能であることが実証された。この結果, COLLAN によって実物炉心の地震応答を概略評価し得 るとの見通しが得られた。

\section{謝辞}

本研究を行うにあたり, 御指導を載いた東京大学大崎 順彦教授に深く感謝の意を表します。武藤構造力学研究 所および電源開発株式会社の方々には，御協力を賜わり ましたことを朽礼申し上げます。また，貴重なデータの 提供や討議に御協力載いたゼネラル・アトミックス社に 感謝いたします。 